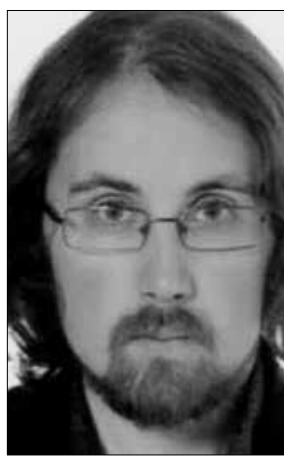

https://doi.org/10.24101/logos.2017.63

Gauta 20170530

\title{
ALFREDAS BUIKO
}

Vilniaus Universitetas, Lietuva

Vilnius University, Lithuania

\section{ANAPUSINIO DIEVO SAMPRATA KARLO BARTHO RELIGIJOS FILOSOFIJOJE \\ The Conception of Otherworldly God in Karl's Barth's Philosophy of Religion}

SUMMARY

The idea of a God that is radically transcendent to immanent reality proposed by theologian and philosopher of religion Karl Barth has transformed the theology in XXth century. This article examines the ways other thinkers have influenced Karl's Barth's theological ideas, Furthermore, it also deals with the conceptions of an otherworldly God and of Christ in Barth's theology and philosophy of religion. Finally, it provides certain criticisms.

\section{SANTRAUKA}

Teologo ir religijos filosofo Karlo Bartho imanentiškai tikrovei radikaliai transcendentiško Dievo samprata transformavo XX a. teologiją. Šiame straipsnyje nagrinėjama kitų mąstytojų įtaka Karlo Bartho teologinėms idejjoms bei analizuojama anapusinio Dievo ir Kristaus sampratos šio autoriaus teologijoje bei religijos filosofijoje, taip pat pateikiama šių sampratų kritika.

\section{IVADAS}

$\mathrm{XX}$ a. teologo ir religijos filosofo Karlo Bartho veikalai radikaliai pakeite šimtmečius gyvavusias Dievo ir tikejjimo sampratas. Šio Austrijoje gimusio, Berne, Berlyne, Tiubingene ir Marienburge studijavusio mąstytojo veikalas Laiškas romiečiams teologo Karlo Adamso buvo pavadintas „bomba, nukritusia i teologu

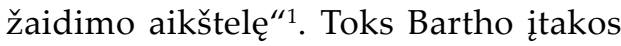
religijos filosofijai apibūdinimas taikliai 
Ł̇vardija šio autoriaus nepaprastai stipru poveiki viso krikščioniškojo pasaulio intelektualiniam sluoksniui, taip pat kaip ir tai, kad Barthas $1956 \mathrm{~m}$. žurnalo "Time“ buvo išrinktas „Metų žmogumi”.

Viena svarbiausių šio autoriaus postuluotų radikaliai naujoviškų krikščionybės koncepciju buvo absoliutus Dievo svetimumas ir transcendentiškumas žmogiškajam pasauliui. Šio straipsnio tikslas - išnagrinèti Bartho Laiške romiečiams aptariamą absoliučiai transcendentiško Dievo koncepciją apžvelgiant galimas įtakas Bartho Dievo koncepcijos susiformavimui bei ivardyti tam tikrus kritiku, tokių kaip Martinas Lutheris Kingas jaunesnysis arba Rudolphas Bultmannas, Bar- thui pateiktus kontrargumentus. Pirmoje dalyje „K. Bartho religijos filosofijos koncepcijos" bus aptarta Soreno Aabe Kierkegaard'o, Fridericho Schleyermacherio ir neokantininku itaka Bartho radikaliai svetimo Dievo idejos formavimuisi. Antros dalies „K. Barto anapusinio Dievo koncepcija“ pirmoje dalyje „Dievas kaip radikaliai transcendentiškas pasauliui" aptariami šios Dievo koncepcijos elementai, o antroje dalyje „Kristaus samprata K. Bartho religijos filosofijoje" aprašomas Bartho pateiktas Kristaus įvaizdis bei šio ivaizdžio svarba Dievo sampratoje. Trečioje dalyje „K. Bartho kritika“ aptariamos kai kurios kritiku pastabos dèl Bartho pateiktos Dievo sampratos.

\section{K. BARTHO RELIGIJOS FILOSOFIJOS KONCEPCIJOS}

Bartho Laiškas romiečiams pasižymi nepaprasta cituojamų tekstų gausa. Nagrinèdamas Pauliaus laiška, Barthas cituoja tokius žymius teologus ir religijos filosofus kaip M. Lutheris ir Sorenas Aabe Kierkegaard'as, o antrojo leidimo pratarmeje jis teigia: „aš niekados nenorèjau nieko daugiau nei klusniai sẻdèti prie tokių mokytų žmonių kaip Hofmannas, J. T. Beckas, Julicheris, Zahnas, Kuhlas ir ju pradininku Tohlerio Meyerio, B. Weisso ir Lipsiuso pèdųㄹ. Būtina pripažinti Bartho ideju ištaku gausa, ir visiškai suprantama, kad skirtingas Bartho teologines koncepcijas, ju susiformavimą galëjo paveikti skirtingų filosofu veikla. Kadangi šiuo straipsniu siekiama išnagrinèti būtent Bartho pateiktą Dievo samprata, šiame skyriuje bus nagrinejamos Bartho studijuotu autorių įtaka būtent šiai jo religinei koncepcijai.
Vienu svarbiausiu filosofu, paveikusių Bartho idejjas, reikètu laikyti danu egzistencialistą S. Kierkegaard'ą: didelè dalis Bartho idejų ne tik primena paties Kierkegaard'o požiūrị i Dieva, religiją ar pasauli, Laiške romiečiams Barthas perima danu filosofo žodyną - vartoja tokius terminus kaip "krisis“, "krikščionija“ arba „absoliutas“. Tiek Kierkegaard'as, tiek Barthas teigia absoliutu Dievo transcendentalumą ir atsietumą nuo kultūrinès plotmès: Kierkegaard'o filosofijoje paklusnumą kultūrinei plotmei (universalumui) ikkūnijantis amžinojo atsisakymo riteris yra žemesnès egzistencijos formos nei religinę patirtị išgyvenęs tikejjimo riteris, o Barthas griežtai kritikuoja mąstytojus, siekiančius paaiškinti Dievą per kultūrinę ar gyvenimo plotmę, teigdamas, jog ju santykis yra ne su transcendentiniu Dievu, bet su ,ne-die- 
$\mathrm{vu}^{\prime \prime}$, kuris yra viso labo fizinio, psichinio arba kultūros pasaulio atspindys - stabas. Kitas svarbus šiu mąstytojų filosofiju panašumas - įsitikinimas dieviškojo pažinimo neracionalumu ir viską išaiškinančio žmogiško proto (taigi ir natūraliosios teologijos kaip siekio protu pažinti Dievą) kritika. Kierkegaard'as teigia, jog vienintelis tikras santykio su Dievu būdas - proto ribu pripažinimas ir ši sekantis „tikëjimo šuolis“, kuri ivykdęs individas peržengia tiek etinę, tiek estetinę būsenas ir sugrį̌ta "perkeistas“: Dievo atradimas - ne racionalaus mąstymo ir filosofavimo pasekmé, bet šio elgesio bergždumo pripažinimas ir ji sekantis valios aktas. Barthui tikejjimas tai „neišvengiama Dievo tikrovè, žvilgsnio tikrumas, ne tyrinejjimo atradimas, bet amžinas suvokimo pagrindas “3, be to, "isitikinimas (belief) yra Tikèjimas (Faith) tik tada, kai jis nèra istoriniu ar dvasinių laimejjimu produktas"4.

Kitas svarbus Barthui mąstytojas religiją kaip "begalybès" (termino, vartojamo ir paties Bartho) intuiciją suvokęs Friedrichas Schleyermacheris, kuris įsitikinęs religijos neredukuojamumu i jokius kitus matmenis 5 . Keturiasdešimt ketveriais metais anksčiau už Kierkegaard'ą skelbęs žinojimo ir religijos radikalią skirtị, Schleyermacheris teigia, jog „aiškinti religiją taip, kaip švietėjai - metafiziniu ir praktiniu protu, - reikštu ją suracionalinti arba redukuoti i etiką prarandant religinès patirties savitumą" ${ }^{\prime \prime}$. Seanas Turchinas pažymi, kad $1912 \mathrm{~m}$. paties Bartho mintys buvo "Schleiermacherio minčių atspindžiai ${ }^{47}$ ir kad Scheiermacheris buvo pirmasis, pateikęs religinès patirties galimybès aprašyma, ivveikiantị Kanto nustatytas ribas patirčiai (ibid: 16).

Trečia Bartho religijos filosofijai svarbių mąstytoju grupè - Marienburgo neokantininkų mokykla. Pasak tyrinètojo McCormako, neokantininku ittaka Bartho veiklai yra dar didesnè nei Soreno Kierkegaard'o, suteikusio tiktai žodyną, o ne „neišsakytus pamatus" (McCormack 1997: 216). Kaip buvo minèta ịvade, Barthas mokèsi teologijos Marienburgo universitete, be to, jis pats pripažista šiu mąstytoju itaką jo veiklai. Iš neokantininkų Barthas perima ,riba, prie kurios protas priverstas sustoti” (nors svarbu pažymèti, jog panašios mintys būdingos ir Kierkegaard'ui).

\section{K. BARTHO ANAPUSINIO DIEVO KONCEPCIJA}

\section{Dievas kaip radikaliai} transcendentiškas pasauliui

Viena svarbiausių Bartho postuluojamų Dievo koncepciju - jo radikalus transcendentalumas visam žmogiškajam „kūno pasauliui“. Kitaip nei neoliberalieji teologai, postulavę tam tikrą Dievo ir pasaulio ryši, Barthas neigia bet kokio bendrumo tarp anapusinio Dievo, jo „be- galybès" ir šio materialaus, žmonių pasaulio galimumą. Kaip pažymi Jacopozzi, Bartho teologinè sistema yra "radikalus pasipriešinimas teologijoje", o pats Barthas „pasipriešino visai XIX a. protestantu teologijai, atsakingai, anot jo, už tai, kad teologija redukuota i̇ žmogiškajją kalbą, pripildytą profaniškojo mokslo, istorijos, filosofijos bei psichologijos" (Jacopozzi 1977: 53). 
Barthas teigia, jog nepaisant ankstesnių mąstytojų veiklos, ankstesni teologai vengè pripažinti ar apmąstyti radikalų Dievo transcendentiškuma, o kartu ir svetimumą pasauliui („Evangelija skelbia absoliutú Dievo svetimumą pasauliui“ (Barth 1968: 28)). Bartho nuomone, Dievo begalybės ir pasaulio baigtinumo skirtumas yra kur kas stipresnis, nei postulavo ankstesni teologai. Šis radikaliai transcendentiško, nebendramačio materialiam pasauliui Dievo vaizdas lemia neigiamą Bartho požiūrị i racionalią arba prigimtinę teologija, siekusią paaiškinti Dievą žmogišku protu. Tačiau Barthas neigia ir religiją: "(tikejjimas) niekados nebūna tapatus istoriniam ir psichologiniam religijos potyriui“" (Barth 1968: 126). Barthas teigia, jog nei religija, nei filosofija, nei kultūra, nei jokia kita žmogiškoji veikla nėra ir negali būti tam tikras kelias, vedantis i Dievo pažinimą: bet kokia žmogiškoji veikla, ipasaulinanti Dieva, bet kuri „,žmogiškaja prerogatyva grista tikèjimo forma yra iliuzija“ (Jacopozzi 1977: 45) ir "sentimentali liberali saviapgaule manyti, jog iš gamtos ir istorijos, iš meno, moralès, mokslo ar net religijos tiesioginiai keliai veda į neįmanomą Dievo galimybę“" (Barth 1968, 37).

Bartho teigimu, senasis požiūris i Dievo ir pasaulio santyki davè pradžią analogia entis, mąstymo apie Dievą tipui, kai siekiama ivvardyti santyki tarp Dievo ir pasaulio (Jacopozzi 1977: 40): Barthas teigia, jog šis mąstymo apie Dievybę būdas lèmé vadinamojo „ne-Dievo“ ìsigalejjimą. Pasak Bartho, žmogus atranda save absoliučioje atskirtyje nuo Dievo (kuri pats Barthas ivvardija kaip „Dievo $\mathrm{Ne}^{\prime \prime}$ ): šis radikalus Dievo ir žmogaus pasaulių nebendramatiškumas ir atsietumas yra pirminè būsena, pirminis būties taškas. Pats Barthas ši potyrį, Dievo Ne ivvardija kaip Dieviškojo teismo patirti (Bultmann 2012: 107), kurią pripažinus, atsiveria Dieviškasis Taip, o kalinys tampa sargybiniu. Šitoks požiūris atskleidžia kantiškąsias Bartho ittakas kaip pažymi Martinas Lutheris Kingas Jr., žmogaus protas negali išeiti už savo ribų ir patirti transcendencijos. Pasak M. L. Kingo, Barthas îsitikinęs, jog šią ribą žmogus gali patirti per „aktą", kuris yra Dievo jam suteikto tikejjimo aktas ir Kristaus bei Šventosios Dvasios veiklos pasekmè (King 1952: 99).

Tačiau analogia entis mąstymo atstovai (kuriems priklausytų ir tokie didūs filosofai kaip Aristotelis, Tomas Akvinietis ar Benediktas Spinoza, tiek senovès pagonys) nepripažista ir ignoruoja šią nepaprastai svarbią skirti ir šitaip sudaiktina Dievą bei, užuot ji garbinę, garbina savo pačių savybes. Analogia entis atstovai, patys to nesuprasdami, iškeičia Dievo Tiesą i žemiškus melus, ir „pusiau sąmoninga pagieža nepažiniam Dievui greitai tampa visiškai sąmoninga" (Barth 1968: 57), o pats Dievas žmonių protuose tampa vis abstraktesnis ir tolimesnis, kol galiausiai jo vietą užima pasaulis, kuris „būna garbinamas ir kuriam tarnaujama - jeigu reikia, ir atskirai nuo Dievo" (ibid). Aprašydamas šią būklę, kai pasaulis užima nepažinaus Dievo vietą žmonių širdyse, Barthas cituoja daktarą F. Straussą: ,pasaulis nebe tiesiog egzistuoja šalia Dievo: jis perèmè Jo vietą ir pats tapo Dievu, ir reikalauja tokio paties atsidavimo, koki senamadis tikintysis duodavo savo Dievui" (Barth 
1968: 52). Tikras tikèjimas neturi nieko bendro su mistišku siekiu praturtinti ši pasauli kito pasaulio „anapus“ sąskaita, jis susijęs su transcendencijos suvokimu (Bultmann 2012: 103).

Barthas teigia, jog Dievas yra visiškai nepažinus ir šis jo visiškas nepažinumas reikalauja radikaliai naujo požiūrio ị Dievą: negalima bandyti paaiškinti Dievo per žmogiškuosius predikatus, nes Dievas yra tai, ko „akis nemate ir ausis negirdejo" (Barth 1968: 70). Kaip naują požiūrị i Dievą Barthas pasiūlo savo analogia fidei - tikèjimo analogija, pripažistančią radikalią Dievo / pasaulio skirti ir nesiekiančią nustatyti begalybès ir baigtinybės santykio. Dievas ir Dievo begalybè negali būti niekaip lyginamos su pasaulio ir žmonių baigtinybe, nes Dievo begalybė yra ne žmonių pasaulio savybių (nors ir pačių geriausių) maksimalus imanomas taškas - tai radikaliai kitokia, radikaliai transcendentiška kitybè.

Analogia fidei mąstymas taip pat teigia, jog žmogus, būdamas radikaliai skirtingas ir neturintis nieko bendro su Dievu, negali net tikètis savo paties jègomis pasiekti Dievo žinojimą: tai gali būti įvykdyta tik Dievui žengus pirmaji žingsni ir save atskleidus per Evangeliją, gerają naujieną. Evangelijos žinia - Dieviškajame Ne (t. y. Dievo radikaliame svetimume pasauliui) slypi ir Dieviškasis Taip (Barth 1968: 38). Barthas sutinka su Kierkegaard'o pastaba, jog „Dievas privalo būti nepažinus, nes tapęs pažinus, jis tampa stabu" (Barth 1968: 38). Kadangi Dievo neįmanoma apmąstyti ar suvokti savo pastangomis, vienintelis kelias į Dievą yra Evangelijoje - Dievo žodyje, kuri Barthas priešina religijai, - slypintis Apreiškimas, kuriuo galima tik tikèti.

\section{Kristaus samprata}

Bartho religijos filosofijoje

Dievo kaip radikaliai svetimo pasauliui teigimas lemia savitą Bartho požiūrị ì Dievo sūnų Kristų. Barthas pripažista Jèzaus Kristaus dieviškumą ir jo, kaip asmens, istoriškumą: tačiau kaip galima paaiškinti šių radikalių priešybių vienybę Kristaus asmenyje? Barthas teigia, jog ši neįmanoma įmanomybė galima ir yra pagrindinė žmogaus santykio su Dievu galimybè.

Barthas teigia: „Jèzus Kristus yra mūsų Viešpats: tai yra Evangelija ir istorijos prasmè. Šiame varde du pasauliai susitinka ir išsiskiria, dvi plokštumos susikerta, viena žinoma, kita nežinoma. Žinoma plokštuma yra Dievo kūrinija, nupuolusi nuo sajungos su Juo, ir todèl „kūno", siekiančio atpirkimo pasaulis: žmonių, daiktų, laiko - mūsų pasaulis" (Barth 1968: 29). Kaip ir Sorenui Kierkegaard'ui, Barthui Jèzaus Kristaus egzistavimas yra paradoksas, taškas, kuriame susitinka kūniškas pasaulis ir absoliutas.

Ypač svarbu pažymèti Bartho daromą Jèzaus - istorinio personažo, veikusio Judejjoje trisdešimtaisiais mūsų eros metais, ir Kristaus - Dievo apsireiškimo - skirti (Bultmann 2012: 115). Jèzus priklauso istorinei realybei, taigi "pasauliui“, kuris, kaip jau buvo aptarta anksčiau, negali būti kelias i transcendentinio Dievo pažinimą. Jėzus iš Nazareto, Dovydo palikuonis, yra vieta, kurioje vyksta dviejų radikaliai skirtingu plokštumų susikirtimas (Barth 1968: 72). Jèzaus Kristaus atliktas stebuklas - nuodèmingo pasaulio pasauliškumo ir „kūniškumo prièmimas“, suteikęs galimybę apreiškimui, tikejjimui ir evangelijai, kurie savo ruožtu yra į Dievo 
anapusybę paties Dievo nutiesti tiltai (King 1952: 60). Tačiau Barthas teigia, kad „(Kristaus) prisikèlime naujasis Šventosios Dvasios pasaulis paliečia kūno pasauli, bet taip, kaip tangentas paliečia skrituli, tai yra jo nepaliesdamas" (Barth
1968: 70). Taigi šis Dievo salytis su pasauliu yra akivaizdžiai paradoksalus, ir todèl žmogiškajam protui nesuprantamas, ir pirmasis žingsnis i i Apreiškimo patirti yra proto kapituliacijos prieš Dievo begalybę ir svetimumą pripažinimas.

\section{BARTHO DIEVO SAMPRATOS KRITIKA}

Bartho Dievo samprata yra susilaukusi tam tikros kritikos: viena pastabu, išsakytu Barthui liberaliuju teologų ir vèliau pakartotų Martino Lutherio Kingo straipsnyje „Bartho Dievo samprata“ yra Dievo imanentiškumo neigimas. Liberalūs teologai irgi pripažista Dievo transcendentiškuma, tačiau jie pripažista ir jo imanentiškumą, mat Dievas išreiškia savo kūrybini genialumą per nuolatini Visatos kūrimą ir palaikymą (King 1952: 106). Bartho radikaliai transcendentinis Dievas šiuo atveju patiriamas tik per "dieviškajij apreiškimą" ir niekaip kitaip, o kiti teologai mato Dievo pédsakus ir šiame jo sukurtame pasaulyje, pvz., žmoniu gerume (ibid).

M. Lutheris Kingas taip pat pasiūlo kitą priekaištą Bartho Dievo sampratai: nepaisant Bartho teiginio, kad Dievas yra nepažinus, ir įsitikinimo, jog apie „Dievą žinome, tik kad apie jị nieko nežinome“, Barthas kalba apie tam tikrus Dievo atributus, tokius kaip teisingumas, didingumas, šventumas su tam tikru tikrumu, nors šitoks yra visiškai nepagrịstas (King 1952: 106). Teigdamas radikalų Dievo ir pasaulio skirtumą bei pripažindamas, jog tarp Dievo ir pasaulio nèra nieko bendro, Barthas turètu arba pripažinti, kad Dievo negalima aprašyti jokiomis žmonèms būdingomis savybèmis (taigi ir kaip teisingą ar šventa, nes šios sąvokos irgi yra žmogiškojo pasaulio sąvokos), arba pripažinti, kad Dievas gali būti pasiektas žmogiškuoju mąstymu, o tam, kaip jau buvo parodyta, Barthas labai prieštaravo.

\section{IŠVADOS}

Karlo Bartho pateikta Dievo samprata paremta radikalios Dieviškojo pasaulio ir žmogiškojo, arba kūno, pasaulio skirties prielaida. Šia samprata paremta religijos filosofija lemia šiuos Bartho Dievo sampratos elementus:

1. Dievas yra absoliučiai netapatus pasauliui, radikaliai transcendentiškas, ir todèl Dievo pažinimas negali būti pasiektas jokiomis pasauliui būdingomis priemonėmis, tokiomis kaip protas, gam- ta, menas, istorija, psichologija ar religija. Žmogus negali pažinti Dievo savo asmeninèmis pastangomis.

2. Radikalus Dievo transcendentiškumas pasaulio atžvilgiu taip pat reiškia, jog transcendentinio Dievo pažinimas gali ịvykti tik paties Dievo malonès dèka, t. y. Dievui, kaip absoliučios begalybès ìsikūnijimui, žengus pirmą žingsnị ir suteikus žmogui tikèjimo galimybę. 
3. Tikëjimas ir i̇sitikinimas yra radikaliai skirtingos sąvokos: tikëjimas - Dieviškosios malonès sąlygotas perèjimas i kitokią egzistencijos būklę, lemiantis asmens transformaciją iš absoliutu pasaulio baigtinumą pripažistančio „kalinio" i pasaulio baigtinumą ir Dievo begalybę suvokiančio "Sargybinio" būtị.

4. Jèzus Kristus yra Dievo apsireiškimas, suteikęs Evangeliją, kuri savo ruožtu igalina tikèjimo malonę - Kristus nutiesia tiltus, t. y. atlieka pirmąji žingsni, leidžiantį žmogui patirti Dievo ir Šventosios Dvasios, absoliučios begalybès nuojautą.

5. Tačiau bartiškoji Dievo koncepcija gali būti ir kritikuotina: visu pirma teigdamas radikalų Dievo svetimumą, Bar-

\section{Literatūra}

Barth, C. 1968: Epistle to Romans. New York: Oxford university press. http://books.google.lt/books?id $=\mathrm{dCEDzQhI} 4 \mathrm{R} 4 \mathrm{C} \&$ printsec $=$ frontcover $\& \mathrm{hl}=\mathrm{lt} \& \mathrm{~s}$ ource $=$ gbs_ge_summary_r\&cad $=0 \# \mathrm{v}=$ snippet\& $\mathrm{q}=$ tangent\&f=false 20131207

Bultmann R. 2012. Karl Barth's epistle to Romans in its second edition. http://www.religion.emory.edu/ faculty/robbins/Pdfs/BultmannBarthRomans.pdf 20121207

Jacopozzi A. 1977. Religijos filosofija. Vertè R. Šerpitytè. Vilnius: Aidai.

King Jr., M. L. 1952. Karl Barth's conception of God. http://www.google.lt/url?sa=t\&rct=j\&q=\&esrc=s

\section{Nuorodos}

1 Sean Turchin, Examining the prime influence on Karl Barth's "Epistle to Romans", second edition, 2008. Liberty University, p. 1.

2 Karl Barth, The Epistle to Romans. New York: Oxford university press, 1968, p. 7.

3 Ten pat, p. 20. thas neigia šio pasaulio gerąsias savybes bei teigia, jog Dievas, suvoktas per pasaulio savybes, yra tik stabas, ne Dievas, be to, teigdamas, jog Dievas yra radikaliai nepažinus, Barthas kalba apie Dievo teisingumą bei kitas Dievo savybes, kurios, kaip žmogiškosios kultūros sukurti dariniai, neturètu būti priskiriamos Dievui (mat jei viskas, ką žinome apie Dieva, yra tai, kad nieko nežinome, jokios Dievo savybès nèra patikrinamos, todèl negali būti teigiamos).

6. Bartho itaka XX a. filosofijai yra didžiulè ir jo Dievo koncepcija atvèré kelią radikaliai naujam Šventojo Rašto ir krikščionybės suvokimui, kas lemia jo kaip teologo svarbą ir populiarumą.

\&source $=$ web\&cd $=1 \&$ ved $=0$ CDAQFjAA\&url $=$ http\%3A\%2F\%2Fmlk-kpp01.stanford.edu $\% 2 \mathrm{~F}$ primarydocuments $\% 2 \mathrm{FVol} 2 \% 2 \mathrm{~F} 520102 \mathrm{Barths}$ ConceptionOfGod.pdf\&ei=se-kUoj-NKq74AS7z 4DIB Q\&usg=AFQjCNENkLk-m6QMmyrwA0S iuc61PgJ3Vg\&sig2=60wyCkp60jnuJaEW0Yc71w \&bvm=bv.57752919,d.bGE, 20121208

McCormack, Bruce. 1997. Karl Barth's critically realistic dialectical theology, Genesis and Development 1909-1936. Oxford University press, UK. Turchin, S. 2008. Examining the prime influence on Karl Barth's "Epistle to Romans" second edition. Liberty University.

\footnotetext{
4 Ten pat.

5 Alfredo Jacopozzi, Religijos filosofija. Iš italų k. vertè R. Šerpitytè. Vilnius: Aidai, 1977, p. 33.

6 Ten pat, p. 36 .

7 Sean Turchin, Examining the prime influence on Karl Barth's "Epistle to Romans", p. 17.
} 